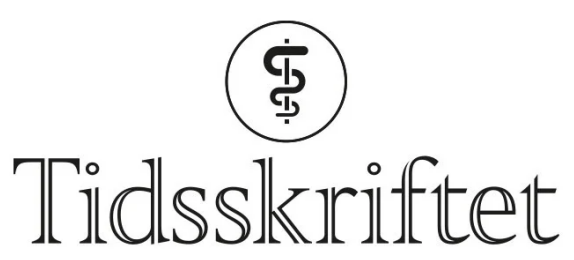

DEN NORSKE LEGEFORENING

\title{
En ung jente med vondt i halsen
}

\author{
NOE Å LAERE AV
}

KATINKA VIGSNAES TAULE

katinka.taule@gmail.com

Barne- og ungdomsavdelingen

Sørlandet sykehus Arendal

Katinka Vigsnæs Taule er lege i spesialisering.

Forfatteren har fylt ut ICMJE-skjemaet og oppgir ingen interessekonflikter.

\section{HAMPUS ERIXON}

Øre-nese-hals avdelingen

Sørlandet sykehus Kristiansand

Hampus Erixon er lege i spesialisering.

Forfatteren har fylt ut ICMJE-skjemaet og oppgir ingen interessekonflikter.

\section{En jente i tenårene ble innlagt ved barneavdelingen grunnet kjevesperre, hevelse på halsen og mistanke om peritonsillær abscess. Utredningen skulle avdekke et mer komplekst symptombilde enn forventet ut fra innleggelsesårsak.}

En ung jente, fra tidligere vesentlig frisk foruten pollenallergi, ble innlagt etter to ukers sykehistorie med halssmerter. Hun var tidlig i forløpet vurdert hos fastlegen, der hurtigtest for mononukleose (Monospot) var negativ. Tilstanden ble tolket som tonsillitt, og pasienten fikk forskrevet en kur med peroral fenoksymetylpenicillin. Grunnet svelgsmerter ble ikke penicillinkuren tatt. Dagene forut for innleggelsen fikk pasienten økende smerter og hevelse på høyre side av halsen samt kjevesperre (trismus). Hun ble innlagt på barneavdelingen med mistanke om peritonsillcer abscess.

Ved innkomst fant man kjevesperre og diffus hevelse på høyre side av halsen, i tillegg til ikteriske sklera. Respiratorisk og sirkulatorisk var hun stabil, med respirasjonsfrekvens 19 per minutt, $\mathrm{SpO}_{2}$ 99 \% på romluft, rektaltemperatur $37,4{ }^{\circ} \mathrm{C}$ og takykardi (puls 117). Blodprøver viste CRP på $143 \mathrm{mg} / \mathrm{L}$ (referanseområde o,oo-5,0), nøytrofile granulocytter på 8,9 109/L (1,5-7,1) og prokalsitonin på o,17 $\mu \mathrm{g} / \mathrm{L}(<0,10)$. Totalbilirubin var økt til $45 \mu \mathrm{mol} / \mathrm{L}\left(5^{-25}\right)$ og konjugert bilirubin til $40 \mathrm{omol} / \mathrm{L}(<5)$. Gammaglutamyltransferase (GGT) var lett økt til $46 \mathrm{U} / \mathrm{L}$ (10-45), normal aspartataminotransferase (ASAT) på 24 U/L (10-45), normal alaninaminotransferase (ALAT) på 23 U/L (10-45) og normal alkalisk fosfatase (ALP) på 298 U/L (referanseområde 35-40o). Mononukleosehurtigtest var negativ. Det ble sikret serologiske prøver for Epstein-Barr-virus (EBV). Pasienten ble isolert grunnet uavklart covid-19-status. Det ble startet intravenøs behandling med benzylpenicillin 1,2 $g \times 4$. 
De vanligste årsakene til halsbetennelse hos barn/ungdom er virusinfeksjoner, inkludert mononukleose, og streptokokkinfeksjoner. De fleste tilfeller med akutt faryngotonsillitt forløper ukomplisert, men i enkelte tilfeller kompliseres forløpet grunnet utvikling av peritonsillær abscess. Klassiske symptomer og funn ved abscessdannelse er kjevesperre og asymmetri i bakre svelgvegg.

Pasienten ble videre unders $ø$ kt av vakthavende øre-nese-hals-lege. Man mistenkte abscedering, men trismus og smerter gjorde at det var vanskelig å få gjennomført en fullgod halsundersøkelse. Det ble derfor rekvirert CT collum. CT-funnene var forenlig med tonsillcer/peritonsillcer abscess bilateralt samt høyresidig trombosert vena jugularis med ledsagende tromboflebitt og flegmonøs betennelse (figur 1). På bakgrunn av dette ble Lemierres syndrom mistenkt. Abscessene ble vurdert som ikke modne for drenering, og det ble anbefalt bytte av antibiotika til klindamycin intravenøst, $600 \mathrm{mg} \times 3$, hvilket ble startet opp neste dag. Grunnet trombosetendensen ble det også forordnet lavmolekylcrt heparin (enoksaparin), dosering 6o mg subkutant morgen og $40 \mathrm{mg}$ subkutant kveld. P-piller (etinyløstradiol) ble seponert, da disse kan gi økt trombosetendens.

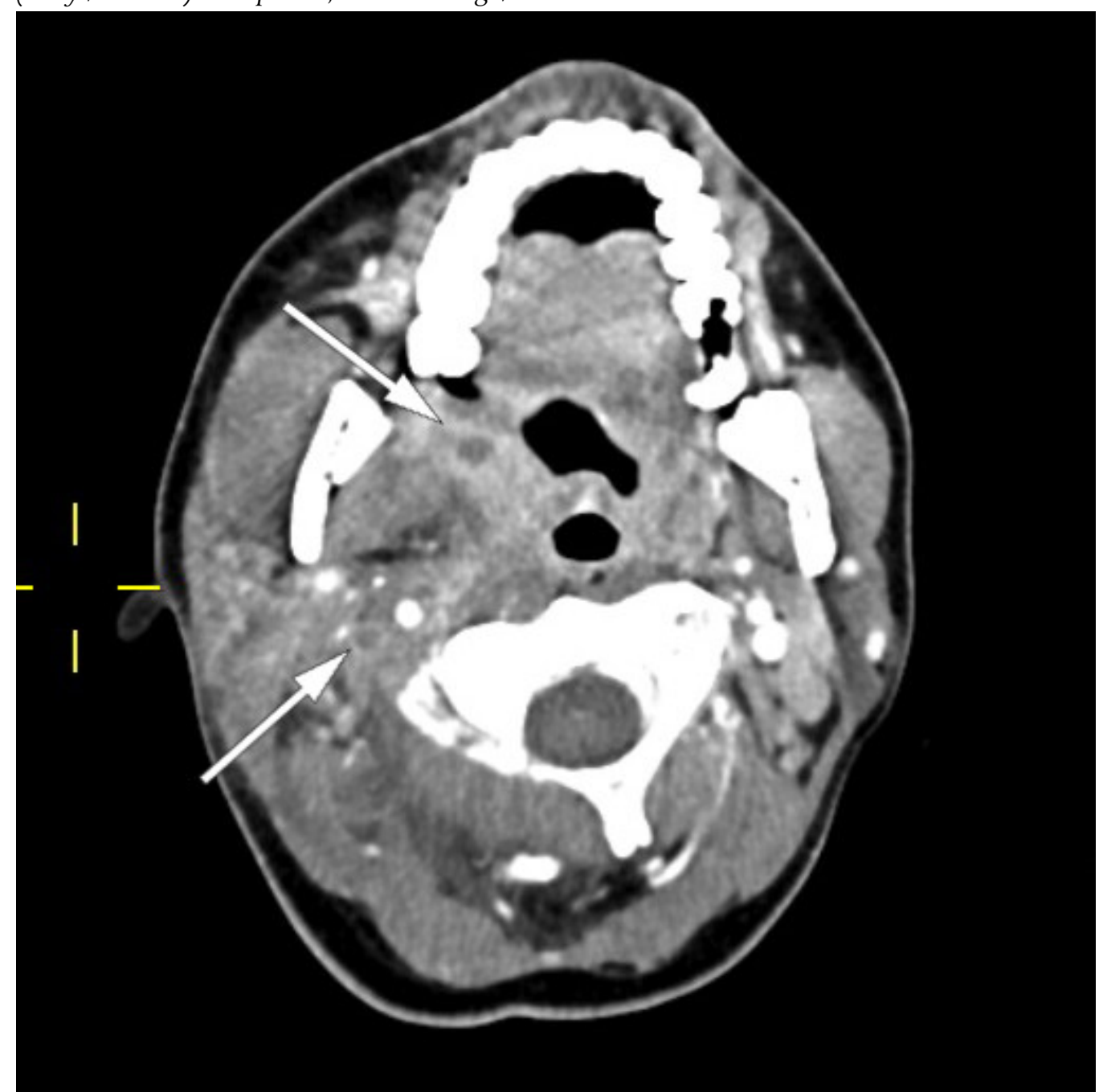

Figur 1 CT collum av vår pasient med Lemierres syndrom, tatt på første innleggelsesdag. Bildet viser peritonsillær abscess og trombosert vena jugularis interna.

I henhold til de nasjonale faglige retningslinjene for antibiotika i sykehus anbefales benzylpenicillin og klindamycin ved peritonsillær abscess, med eventuelt tillegg av metronidazol (1).

Dag 2 var pasienten $i$ bedre allmenntilstand. De vitale parameterne var fortsatt stabile. Biokjemisk så man lett bedring, med CRP-fall til $123 \mathrm{mg} / \mathrm{L}(0,00-5,0)$, normalisering av gammaglutamyltransferase og fall $i$ konjugert bilirubin. Etter konferering med øre-nese-hals-lege valgte man å fortsatt avvente operativ behandling. Infeksjonsmedisineren som ble konsultert, anbefalte å fortsette behandling med klindamycin intravenøst og legge til benzylpenicillin intravenøst. Det ble på dette tidspunktet, omtrent ett døgn etter oppstart med antibiotika, sikret blodkulturer. 
Hos febrile pasienter innlagt i sykehus er det anbefalt å sikre blodkulturer før oppstart med antibiotika. Dette gir høyeste sannsynlighet for å påvise mikroorganismer i blodet samt raskest mulig resistensbestemmelse. Blodkulturer hos vår pasient ble dessverre ikke sikret før omtrent ett døgn etter antibiotikaoppstart.

Pasienten fikk smerter i venstre del av toraks på dag 2. CT toraks og abdomen viste funn forenlig med septiske embolier i begge lunger og mulig infarktkomponent i høyre underlapp (figur 2, figur 3). I tillegg var det lett forstørret lever og milt, periportalt ødem samt små mengder fri vceske i bekkenet (muligfysiologisk). Det var også beskrevet mistanke om tromber i vena subclavia og vena axillaris på høyre side. Dag 3 så man oppvekst av penicillinfølsomme Streptococcus anginosus i blodkultur. Serologiske prøver viste svakt positivt Epstein-Barr-virus (EBV)-viralt kapsidantigen (VCA)-IgG, svakt positivt EBV-VCA-IgM og negativt EBV-EBNA-IgG. Intravenøst benzylpenicillin og klindamycin samt antikoagulasjonsbehandling med lavmolekylart heparin (enoksaparin) ble kontinuert.

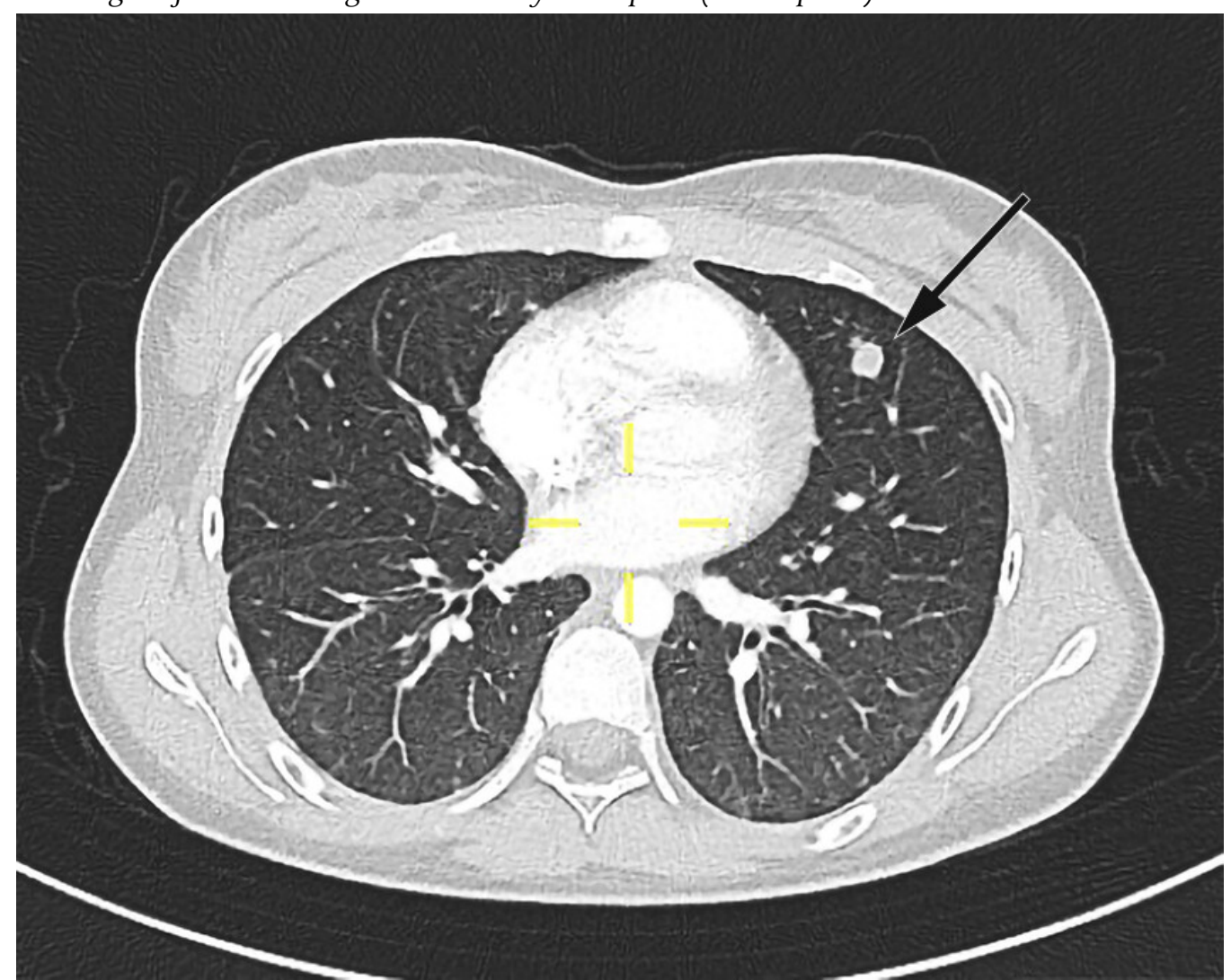

Figur 2 CT-bilde av pasientens lunger tatt på andre innleggelsesdag. Bildet viser en rundfortetning i venstre overlapp. Den er lavattenuerende sentralt og kan godt representere en septisk embolus. 


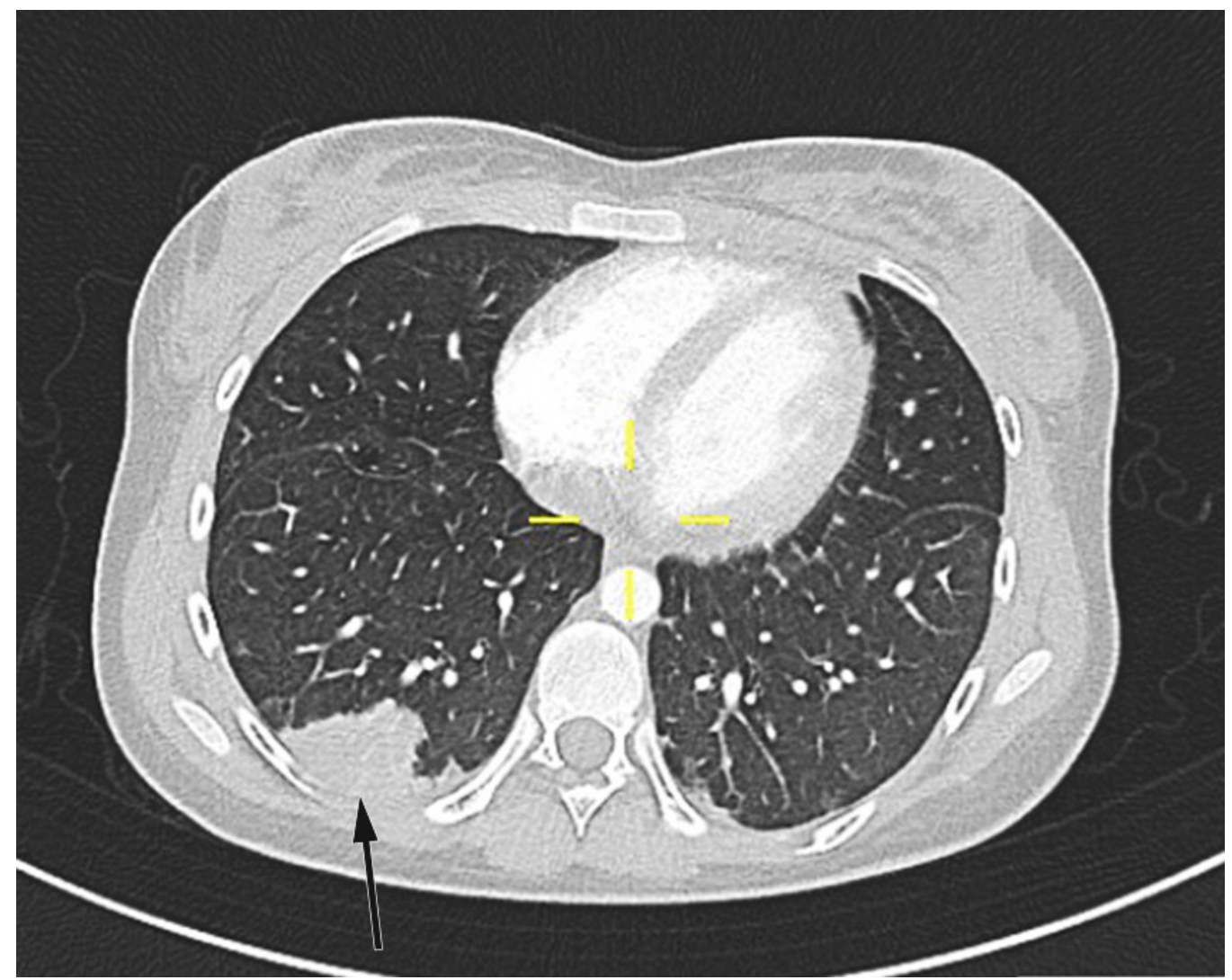

Figur 3 CT-bilder av pasientens lunger tatt på andre innleggelsesdag. Bildet viser et infarkt i høyre underlapp. Sannsynlig årsak er en okkludert pulmonalarterie, trolig grunnet en septisk embolus.

MR collum på dag 3 viste relativt uendret bilde med tonsillcere/peritonsillcere abscesser bilateralt, utbredt cellulitt/ødem i bløtdeler og vedvarende trombose i vena jugularis. Bildene ble vurdert av ørenese-hals-leger, som fant indikasjon for tonsillektomi. Grunnet blødningsrisiko og usikkerhet rundt antikoagulasjonsindikasjonen ble enoksaparin nullet dagen før operasjon.

Pasienten ble dag 4 tonsillektomert à chaud. Inngrepet ble utført i generell narkose. Kjevesperre $i$ forbindelse med peritonsillcer abscess er et stort varselsignal om forventet vanskelig luftvei ved intubasjon. Pasienten ble maskeventilert og deretter intubert med videolaryngoskop (C-MAC). Ingen komplikasjoner oppstod. Bakterien Streptococcus anginosus ble gjenfunnet ved dyrkning av puss fra abscessen. Det ble ikke utført PCR-undersøkelse av evakuert puss. Tonsillene ble sendt til histologisk undersøkelse, som viste kronisk aktiv betennelse og ingen atypi.

Tonsillektomi à chaud betyr direkte oversatt varm tonsillektomi. Vanligvis gjøres tonsillektomi i infeksjonsfrie perioder, såkalt kald fase. Tonsillektomi à chaud gjøres altså når det kreves et akutt inngrep. Dette kan gjøres på mekanisk grunnlag, for eksempel ved mononukleose med tonsillehypertrofi som gir alvorlig dyspné, eller på infeksiøst grunnlag der det er risiko for spredning av infeksjonen. I vårt tilfelle fryktet man at infeksjonen skulle spre seg via det parafaryngeale rom ned til mediastinum.

Pasienten ble observert ett døgn postoperativt ved øre-nese-hals-avdelingen, før hun på dag 5 ble overflyttet tilbake til barneavdelingen. Videre kontinuerte man behandling med intravenøs antibiotika og avventet reoppstart av antikoagulasjonsbehandling. De neste dagene var pasienten $i$ klinisk bedring. Hevelsen på halsen avtok, pasienten var mindre smertepreget og fikk bedre appetitt. Pasienten hadde til å begynne med morfinkrevende smerter i toraks, men disse avtok, og hun hadde etter hvert god effekt av kun paracetamol og ibuprofen ved behov. Infeksjonsprøver og lever-galleprøver normaliserte seg. Ekkokardiografi viste normale funn.

Pasienten ble utskrevet til hjemmet på dag 8. Grunnet septiske embolier var det planlagt totalt seks uker behandling med intravenøs antibiotika, utført av hjemmesykepleien $i$ kommunen.

På dag 12, åtte dager postoperativt, ble pasienten reinnlagt ved øre-nese-hals-avdelingen med postoperativ blødning. Ved innkomst var pasienten sirkulatorisk stabil, og blødningen hadde avtatt. Det ble observert et koagel i venstre nedre tonsillelosje. Koagelet ble fjernet, og det ble ikke funnet 
pågående blødning. Pasienten ble observert i ytterligere ett døgn, ingen tegn til reblødning, før hun ble utskrevet til hjemmet i god allmenntilstand.

Videre bruk av antikoagulasjonsmidler ble diskutert flere ganger i kollegiet, og flere ulike instanser både sentralt og lokalt ble konsultert. Konsensus ble til slutt at man anbefalte antikoagulasjonsbehandling så lenge blødningsrisikoen postoperativt ble ansett som lav. Initialt ble det anbefalt å avvente oppstart til dag 10 postoperativt, men grunnet den postoperative blødningen ventet man til dag 14 etter operasjonen. Valget av antikoagulasjonsmidler falt til slutt på rivaroksabantabletter $(15 \mathrm{mg} \times 2 \mathrm{i}$ tre uker, deretter $20 \mathrm{mg} \times 1$ i tre måneder).

Etter nesten fire ukers behandling med benzylpenicillin og klindamycin, samt tre dagers behandling med rivaroksaban, utviklet pasienten en allergisk reaksjon med legemiddelbetinget hudutslett, tolket som DRESS (drug reaction/rash with eosinophilia and systemic symptoms). Pasienten ble anbefalt å avstå fra disse tre legemidlene $i$ tiden fremover, og antibiotikakuren ble derfor avsluttet etter totalt fire uker. Rivaroksaban ble byttet til dalteparin injeksjonsvceske 5 ooo IE subkutant $\times 2$, totalt tre måneders behandlingstid.

Ved poliklinisk kontroll tre måneder etter diagnosetidspunktet var pasienten $i$ god allmenntilstand. Hun var fullstendig symptomfri, hadde normal hematologisk status og normale funn på røntgen toraks. Det er planlagt avsluttende kontroll med spirometri på et senere tidspunkt.

\section{Diskusjon}

Lemierres syndrom forekommer sjelden, men er alvorlig. Syndromet har ingen standarddefinisjon, og ulike kriterier har blitt brukt. I 1936 beskrev André Lemierre syndromet slik: nylig orofaryngeal infeksjon, trombose i vena jugularis, anaerobe mikrober og oftest septiske embolier. Syndromet hadde tidligere høy mortalitet, og pasientene døde som oftest innen 7-15 dager (2) $)$. Etter at antibiotika ble introdusert, har dødeligheten sunket betraktelig, og mortalitetsraten er i nyere tid $5-9 \%(3,4)$.

Syndromet rammer gjerne friske og unge pasienter. En dansk studie viste en insidens på 14,4 per million i aldersgruppen 15-24 år. Generelt i befolkningen viste samme studie en insidens på 3-6 tilfeller per million (5).

Det vanligste presentasjonssymptomet er faryngitt, gjerne ledsaget av tonsillehypertrofi og feber. Bakterien sprer seg etter hvert til vena jugularis og gir suppurativ tromboflebitt. Dette fører til ømhet og/eller hevelse over jugularisvenen, kjevevinkelen eller langs sternokleidomastoideusmuskelen. Videre kan infeksjonen spre seg hematogent, og septiske emboluser oppstår. Hyppigst ses hematogen spredning til lungene, som affiseres i $85 \%$ av tilfellene (므). I lungene oppstår det hyppigst nekrotiske lesjoner, men man kan også se infiltrater, pleuraeffusjon, empyem, lungeabscesser og nekrotiserende mediastinitt (므). Det er i tillegg beskrevet tilfeller med ledsagende septisk artritt og/eller osteomyelitt, milt-, lever- og nyreabscesser, endokarditt, perikarditt samt epiduralabscesser og hjerneabscesser (2) $)$.

Lemierres syndrom starter i $85 \%$ av tilfellene med infeksiøst fokus i tonsillene (2ㅁ). Det er imidlertid vist at man kan utvikle syndromet med fokus andre steder, som øyne, bihuler, ører og gastrointestinalkanalen (3).

Fusobacterium necrophorum er vanligste påviste patogen, men syndromet kan også skyldes Fusobacterium necleatum, Klebsiella pneumoniae samt anaerobe streptokokker og stafylokokker (2). Hos den aktuelle pasienten var det oppvekst av Streptococcus anginosus både i blodkultur og i abscessinnholdet fra høyre tonsill. Denne anaerobe bakterien inngår i Streptococcus anginosus-gruppen, som tidligere gikk under navnet Streptococcus millerigruppen. Bakterien er en grampositiv kokk som er kjent for å danne abscesser (ㅁ).

Det er beskrevet at mononukleose kan disponere for infeksjon med Fusobacterium necrophorum. Potensielle forklaringer på dette er lymfeobstruksjon og immunologiske faktorer (7.). Det er imidlertid også rapportert om tilfeller med falskt positiv Monospot-test 
ved Fusobacterium necrophorum-infeksjoner (7.). Hos den aktuelle pasienten ble det initialt påvist svakt positivt EBV-VCA-IgG, svakt positivt EBV-VCA-IgM og negativt EBV-EBNA-IgG. Senere tester var alle negative for Epstein-Barr-viruset, og vi har tolket de første prøvene som falskt positive.

Behandling av Lemierres syndrom krever tverrfaglig samarbeid. Som empirisk antibiotikabehandling er benzylpenicillin i monoterapi ikke anbefalt grunnet betalaktamaseproduksjon hos patogenene. Det er anbefalt empirisk å forskrive betalaktamaseresistente antibiotika med anaerob aktivitet, for eksempel klindamycin, metronidazol eller piperacillin/tazobaktam, i kombinasjon med betalaktamantibiotika ( $\underline{8})$. Det er ingen klare retningslinjer for behandlingslengde. I en oversiktsartikkel fra Belgia er det angitt at behandlingslengden varierer fra 2-4 uker til 20 uker, med gjennomsnitt på 5 uker (ㅁ). Samme artikkel angir også en anbefalt minimumslengde på 14 dager, men det presiseres at behandlingen må tilpasses sykdomsforløpet.

For antikoagulasjonsbehandling er det heller ingen klar konsensus, da det ikke finnes noen kontrollerte studier. I en litteraturgjennomgang publisert i International Journal of Angiology angis det at antibiotika og drenasje er den viktigste behandlingen ved Lemierres syndrom (9.). Artikkelen anbefaler at antikoagulasjonsbehandling vurderes hos høyrisikopasienter med uttalt trombose i vena jugularis interna og ved manglende effekt av antibiotikabehandling (9.).

Pasienten og hennes foresatte har gitt samtykke til at artikkelen blir publisert. Vi ønsker å takke radiolog Birger Breivik for hjelp med å tolke og illustrere CT-bildene. Artikkelen er fagfellevurdert.

\section{LITTERATUR}

1. Helsedirektoratet. Retningslinjer for antibiotika i sykehus - komplisert tonsilitt. https://www.helsedirektoratet.no/retningslinjer/antibiotika-i-sykehus Lest 26.4.2021.

2. Lee WS, Jean SS, Chen FL et al. Lemierre's syndrome: A forgotten and re-emerging infection. J Microbiol Immunol Infect 2020; 53: 513-7. [PubMed][CrossRef]

3. Karkos PD, Asrani S, Karkos CD et al. Lemierre's syndrome: A systematic review. Laryngoscope 2oog; 119:1552-9. [PubMed][CrossRef]

4. Sacco C, Zane F, Granziera S et al. Lemierre syndrome: Clinical update and protocol for a systematic review and individual patient data meta-analysis. Hamostaseologie 2019;39: 76-86. [PubMed] [CrossRef]

5. Hagelskjaer Kristensen L, Prag J. Lemierre's syndrome and other disseminated Fusobacterium necrophorum infections in Denmark: a prospective epidemiological and clinical survey. Eur J Clin Microbiol Infect Dis 2008; 27: 779-89. [PubMed][CrossRef]

6. Gossling J. Occurrence and pathogenicity of the Streptococcus milleri group. Rev Infect Dis 1988; 10: 257-85. [PubMed][CrossRef]

7. Riordan T. Human infection with Fusobacterium necrophorum (Necrobacillosis), with a focus on Lemierre's syndrome. Clin Microbiol Rev 2007; 20: 622-59. [PubMed][CrossRef]

8. Moretti M, De Geyter D, Goethal L et al. Lemierre's syndrome in adulthood, a case report and systematic review. Acta Clin Belg 2020; 75: 1-11. [PubMed][CrossRef]

9. Phua CK, Chadachan VM, Acharya R. Lemierre syndrome-should we anticoagulate? A case report and review of the literature. Int J Angiol 2013; 22: 137-42. [PubMed][CrossRef]

Publisert: 20. juli 2021. Tidsskr Nor Legeforen. DOI: 10.4045/tidsskr.20.0991

Mottatt 1.12.2020, første revisjon innsendt 11.2.2021, godkjent 26.4.2021.

Publisert under åpen tilgang CC BY-ND. Lastet ned fra tidsskriftet.no 26. april 2023. 